This PDF is a selection from a published volume from the National Bureau of Economic Research

Volume Title: Managing Currency Crises in Emerging Markets

Volume Author/Editor: Michael P. Dooley and Jeffrey A.

Frankel, editors

Volume Publisher: University of Chicago Press

Volume ISBN: 0-226-15540-4

Volume URL: http://www.nber.org/books/dool03-1

Conference Date: March 28-31, 2001

Publication Date: January 2003

Title: Does It Pay to Defend against a Speculative Attack?

Author: Barry Eichengreen, Andrew K. Rose

URL: http://www.nber.org/chapters/c9647 


\title{
Does It Pay to Defend against a Speculative Attack?
}

\author{
Barry Eichengreen and Andrew K. Rose
}

\subsection{Introduction}

This paper adds an observation to the stock of empirical regularities in the literature on speculative attacks. Comparing the behavior of successful attacks on pegged exchange rates with successful defenses (instances when a speculative attack occurred but did not precipitate a significant change in the prevailing rate), we show that there are costs of failing to successfully defend against the attack. These are equivalent to approximately a year of economic growth, or 3 percentage points of gross national product (GNP). However, the output losses that follow successful attacks are only evident for short periods; the difference between successful attacks and successful defenses is significant for just one year.

This finding helps to account for a number of observations about the behavior of open economies and their policy makers.

Barry Eichengreen is the George C. Pardee and Helen N. Pardee Professor of Economics and Political Science at the University of California at Berkeley, a research associate at the National Bureau of Economic Research, and a research fellow at the Centre for Economic Policy Research. Andrew K. Rose is the B. T. Rocca Jr. Professor of Economic Analysis and Policy in the Haas School of Business at the University of California, Berkeley, a research associate at the NBER, and a research fellow at the Centre for Economic Policy Research.

The authors thank Carlos Arteta and Galina Hale for research assistance; the National Science Foundation, the Ford Foundation, and the World Society Foundation for financial support; Cam Harvey, Aart Kraay, David Leblang, and Gian Maria Milesi-Ferretti for help with data; and Allan Drazen, Kenneth Kletzer, Richard Portes, and conference participants for comments. The analysis was begun while Rose visited the Reserve Bank of New Zealand and Victoria University in Wellington; he thanks those institutions for hospitality and support. The STATA data set used to generate the results is available at [http://haas.berkeley.edu/ arose]. 
- Readiness to mount a defense. We regularly observe governments and central banks undertaking difficult policy adjustments (sharp hikes in interest rates, large fiscal cuts) in order to defend their currencies, despite objections that these policies may precipitate a recession. Our finding explains this behavior: the output costs of the alternative-failure to defend the currency - can be even higher.

- International Monetary Fund (IMF) exchange rate advice and conditionality. Although the IMF has repeatedly urged its members to abandon soft pegs in favor of greater exchange rate flexibility, it has also extended generous financial assistance to countries seeking to defend their currencies against attack. ${ }^{1}$ Again, our finding helps to explain this behavior: exiting a peg in a crisis tends to result in costly output losses, something that the IMF as well as the national authorities wish to avoid.

- The V-shaped recovery from the Asian crisis. A number of observers have commented on the "V-shaped" recovery of the Asian countries from their 1997-98 crisis (sharp falls in output were followed by equally sharp recoveries after an interval of one to two years). We show that, rather than reflecting unique characteristics of Asia's crisis or its economies, as is sometimes suggested, this pattern is quite general. ${ }^{2} \mathrm{It}$ is the typical response of output to a successful attack.

The question is whether this post-crisis behavior of output is a consequence of the success of the attack or simply a reflection of the causes of that outcome. Is it the resolve to mount a successful defense that determines the subsequent behavior of output, or is it the behavior of output (and associated variables) that determines the success or failure of the attack? To put the same point another way, is it the decision of how to respond to the speculative attack that shapes the subsequent performance of the economy, or do countries that are unable to defend their currencies have other problems that both render them unable to beat back the speculators and contribute to the severity of their post-crisis recessions?

The benefit of the doubt should be given to the view that it is differences in the pre-crisis characteristics of economies that explain both differences

1. In the words of the managing director, "Experience has shown that heavily managed or pegged exchange rate regimes can be tested suddenly by exchange markets, and that it can be very costly either to defend them or to exit under disorderly circumstances. On balance, we have a responsibility to advise our members that while such regimes can succeed, the requirements for a country to maintain a pegged or heavily managed exchange rate are daunting - especially when the country is strongly engaged with international capital markets" (Koehler 2001, 3-4).

2. Thus, authors like Sachs and Stiglitz have pointed to the quick rebound of output in countries like Korea as evidence that their crises reflected problems of investor panic rather than flawed fundamentals like those that underly currency crises in many other emerging markets. Insofar as our results suggest that there was nothing special about the nature of the postcrisis behavior of output, such inferences become more difficult to draw. 
in their abilities to rebuff a speculative attack and differences in the postattack behavior of output. Imagine, for example, that growth is weakening and unemployment is rising. The authorities will then be less ready to employ higher interest rates to defend the currency. Knowing this, speculators will have more incentive to attack and a greater likelihood of success (Jeanne 1997). To the extent that output movements are persistent, postcrisis macroeconomic performance will be disappointing. However, it is not the success or failure of the attack that determines the behavior of output; rather, it is the behavior of output that determines the success or failure of the attack. To put the point another way, it is a third variable (the pre-crisis state of the economy) that determines the response of both policy makers and the economy to the crisis. ${ }^{3}$

Given this presumption, it is striking that we are unable to detect differences in the pre-crisis state of the economy that can explain the very different post-crisis performance in cases where speculative attacks succeed and cases where they fail.

- The behavior of output appears to be no different prior to successful attacks and prior to successful defenses.

- The behavior of other economic and financial variables appears to be no different prior to successful attacks and prior to successful defenses.

- The behavior of a variety of political variables appears to be no different prior to successful attacks and prior to successful defenses.

- Econometric techniques designed to account for unobservable differences in countries mounting successful and unsuccessful defenses do not weaken the finding of significant differences in the subsequent behavior of output.

- The addition of country credit ratings as a way of capturing otherwise unquantifiable economic and financial vulnerabilities changes none of our findings.

- Our key results survive a battery of additional sensitivity analyses.

Although the facts are clear, their implications are less so. Our preferred interpretation is as follows. Failure to successfully defend a currency against attack is a shock to confidence. Involuntary abandonment of the exchange rate regime that previously served as the nominal anchor for policy raises doubts in the minds of the markets about the prospects for stability. We thus observe a loss of policy discipline following a successful attack: the growth of the money base accelerates, and inflation rises (relative to cases

3. One can imagine a variety of other plausible arguments working in the same direction. For example, a heavy load of short-term foreign currency-denominated debt could both make governments less willing to raise interest rates to defend the currency (since higher interest rates will raise debt-servicing costs) and make the post-crisis economic performance weaker (since devaluation will make life more difficult for firms whose debts are denominated in foreign currency but whose revenues are domestic currency denominated). 
in which the speculative attack is successfully rebuffed). Risk premia rise, depressing consumption and investment. Only countries that succeed in establishing a clear and credible alternative monetary anchor succeed in avoiding these costs. Examples that spring to mind include the United Kingdom and Sweden, which embraced inflation targeting, first implicitly and then formally, following their 1992 crises; Italy's continued commitment to European monetary unification following its ejection from the exchange rate mechanism (ERM); and Brazil's resort to inflation targeting following involuntary abandonment of its exchange rate peg in early 1998.

We establish these points in our paper, which is organized as follows. Section 3.2 describes the data and their characteristics. Section 3.3 then subjects them to multivariate analysis. Section 3.4 reports the results of a series of sensitivity analyses. Section 3.5, in concluding, returns to the broader implications of our findings.

To avoid confusion, we should reiterate what we do and do not set out to establish in this paper. Our concern is to compare post-crisis economic performance in cases in which the speculative attack succeeds and those in which it fails. It is to show that there is little evidence of differences in the pre-crisis structure and performance of the economies falling into these two categories that can help to account for the apparent different postcrisis outcomes. Our concern is not whether there are differences between countries that do and do not experience speculative attacks. The latter is a separate question. It is the subject of a different literature (much of which purports to identify leading indicators of currency crises). It is not our topic here.

\subsection{Data}

The macroeconomic and financial data used in this paper were extracted from the 2000 World Development Indicators CD-ROM produced by the World Bank. ${ }^{4}$ They are annual and cover the period 1960-98. We consider essentially all middle- and high-income countries with average populations

4. The macroeconomic and financial variables we utilize include real GDP, private consumption, the consolidated government budget deficit (as a percent of GDP), the official bilateral dollar exchange rate, gross international reserves, the ratio of reserves to imports, the current account balance (as a percent of GDP), exports and imports of goods and services, total debt service (as a percent of GNP), deposit and lending rates (in percent), the interest rate spread (defined as the lending rate minus LIBOR), the consumer price index inflation rate, M1 and M2, credit to the private sector (as a percent of GDP), banking sector credit to the private sector (as a percent of GDP), and the market capitalization of listed companies (as a percent of GDP). The data set was checked and corrected for outliers and transcription errors. In addition, we use series on capital controls from the IMF's annual report on Exchange Arrangements and Exchange Restrictions, country credit ratings from Institutional Investor, and political variables kindly provided by David Leblang. 
of at least one million (eighty-nine in number, of which fifty-seven experience at least one crisis during the sample period). ${ }^{5}$

Our country sample is chosen to align closely with that used in Kraay (1998), enabling us to use that author's crisis dates. ${ }^{6}$ Kraay defines a successful attack as the first observation following a year of stable exchange rates when the rate of currency depreciation exceeds 10 percent. ${ }^{7}$ Failed attacks are defined as episodes when nongold reserves decline by at least 20 percent after a year in which neither a successful nor a failed attack occurred. ${ }^{8}$

We begin with simple comparisons of economic and financial variables before and after successful attacks and successful defenses. In both cases, the average behavior of the variable in question is compared to the average behavior of the same variable for noncrisis periods - that is, tranquil peri-

5. The exact list of countries is (in order of World Bank country code): Albania; United Arab Emirates; Argentina; Australia; Austria; Belgium; Bulgaria; Bolivia; Brazil; Brunei; Botswana; Canada; Switzerland; Colombia; Costa Rica; Cuba; Cyprus; Czech Republic; Germany; Denmark; Dominican Republic; Ecuador; Egypt; Spain; Finland; France; Gabon; United Kingdom; Greece; Guatemala; Hong Kong; Hungary; Indonesia; Ireland; Iran Islamic Rep.; Iraq; Israel; Italy; Jamaica; Jordan; Japan; Korea; Kuwait; Lebanon; Libya; Morocco; Mexico; Macedonia FYR; Mauritius; Malaysia; Namibia; the Netherlands; Norway; New Zealand; Oman; Peru; the Philippines; Papua New Guinea; Poland; Korea Dem. Rep.; Portugal; Paraguay; Singapore; Slovak Republic; Sweden; Syrian Arab Republic; Thailand; Trinidad and Tobago; Tunisia; Turkey; Uruguay; United States; Venezuela; Yugoslavia FR (Serbia/Montenegro); and South Africa. Kraay does not actually list his countries, but we have followed his description as closely as possible.

6. Among other things, this frees us of the objection that we have selected successful and unsuccessful attacks as a function of the subsequent behavior of output (especially since the purpose of Kraay's paper - to analyze the efficacy of the interest rate defense - is independent of our research).

7. Kraay writes: "I first identify all episodes in which the one-month depreciation rate (i.e., the increase in the nominal exchange rate) exceeds $10 \%$, which is roughly two standard deviations above the mean depreciation rate for the entire sample. In order for these large depreciations to be meaningfully considered successful speculative attacks, it is necessary that the exchange rate be relatively fixed prior to the depreciation itself. Accordingly, for each observation I construct the average over the previous twelve months of the absolute value of percentage changes in the nominal exchange rate. I then eliminate all large depreciation episodes for which this average exceeded $2.5 \%$, or about one half of one standard deviation from the mean for the entire sample. I define these events as successful speculative attacks. Finally, in order to avoid 'double-counting' prolonged crises in which the nominal exchange rate depreciates sharply for several months, I further eliminate successful attacks that were preceded by successful attacks in any of the prior twelve months."

8. Again, to quote Kraay: "To identify unsuccessful speculative attacks, I first consider all episodes in which the monthly decline in non-gold reserves exceeds $20 \%$, which is about two standard deviations above the mean decline in reserves for the entire sample. In order to restrict attention to large reserve losses incurred defending relatively fixed exchange rates, I eliminate all those episodes for which the same moving average of absolute values of changes in the nominal exchange rate as before was greater than $2.5 \%$. Next, to eliminate large reserve losses accompanying successful attacks, I exclude all episodes in which the change in the nominal exchange rate in the same month or any of the three following months was greater than $10 \%$. I define these episodes as failed speculative attacks and, as before, I eliminate all failed attacks that are preceded by a failed attack in any of the twelve previous months." 
ods in which neither successful attacks nor successful defenses occur-and surrounded by a $2-$ standard deviation band.

Figures 3.1 and 3.2 portray the variables of interest from three years prior to three years after the event. Figure 3.1 considers domestic variables, figure 3.2 external variables, for our 92 successful attacks and 184 failed attacks. Adding a three-year exclusion window to ensure that we do not double-count crisis observations (note that this is the same exclusion window that we use in the formal statistical analysis that follows) does not change the results.

Consider first the two top-left-hand panels of figure 3.1, which display GNP growth around the time of successful attacks and successful defenses. They show that growth rate averages about 3 percent in the three years preceding both successful attacks and successful defenses. This is quite close to the average in noncrisis periods (as denoted by the horizontal line). Growth then falls sharply, to barely zero, in the year of a successful attack and the year following, before recovering to pre-attack levels. In contrast, there is little change in growth rates either before or after successful defenses.

We can reject at the 99 percent confidence level that the post-crisis behavior of output is the same in countries that succumb to attacks and those that mount successful defenses. Here, then, the first key result of this paper makes its appearance.

The other panels hint at what may be driving these differences in postcrisis performance. Narrow money (M1) growth and inflation rise in the wake of successful attacks but not in the wake of successful defenses, suggesting a loss of monetary discipline when defense of the currency is abandoned. ${ }^{9}$ Consumption and investment growth both fall, despite the decline in real interest rates that accompanies the acceleration in inflation, further suggesting a loss in confidence. ${ }^{10}$ Interest rate spreads (defined as the lending rate minus London Interbank Offered Rate [LIBOR]) rise following successful attacks, again suggesting declining confidence and rising risk perceptions.

However, there are no comparable differences in the behavior of any of these variables in the three years preceding the event. Growth is no different in the run-up to successful attacks and successful defenses. Inflation and money growth are no different. Budget deficits are no different. It is not obvious, in other words, that differences in the precrisis development of these macroeconomic variables explain the different outcome of the speculative attack. $^{11}$

9. The difference in M1 growth between successful and unsuccessful defenders just misses statistical significance at the 95 percent confidence level. The difference in inflation does not approach significance at conventional confidence levels.

10. The difference in post-crisis real interest rates between successful and unsuccessful defenders is statistically significant at the 95 percent confidence level, but the difference in postcrisis consumption growth is not. (The same is true of investment.)

11. Formal statistical tests show that none of these variables behaves significantly differently at anything approaching standard (95 percent) confidence levels in the year preceding the event. 

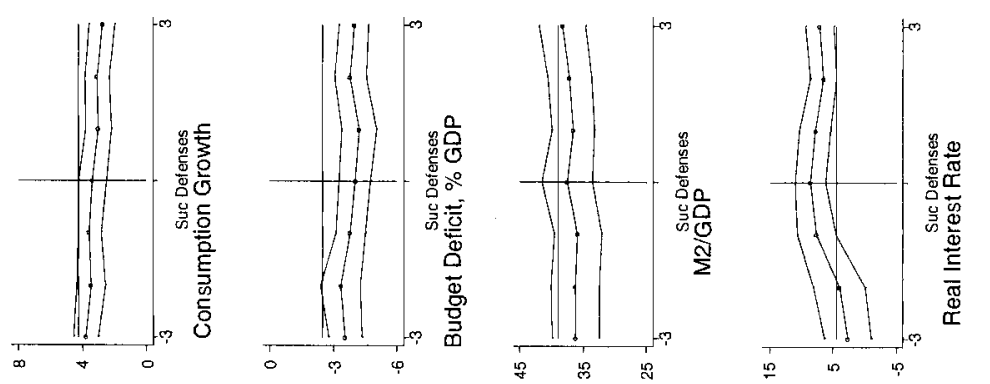

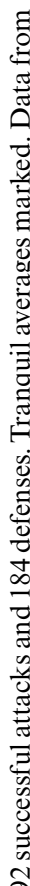
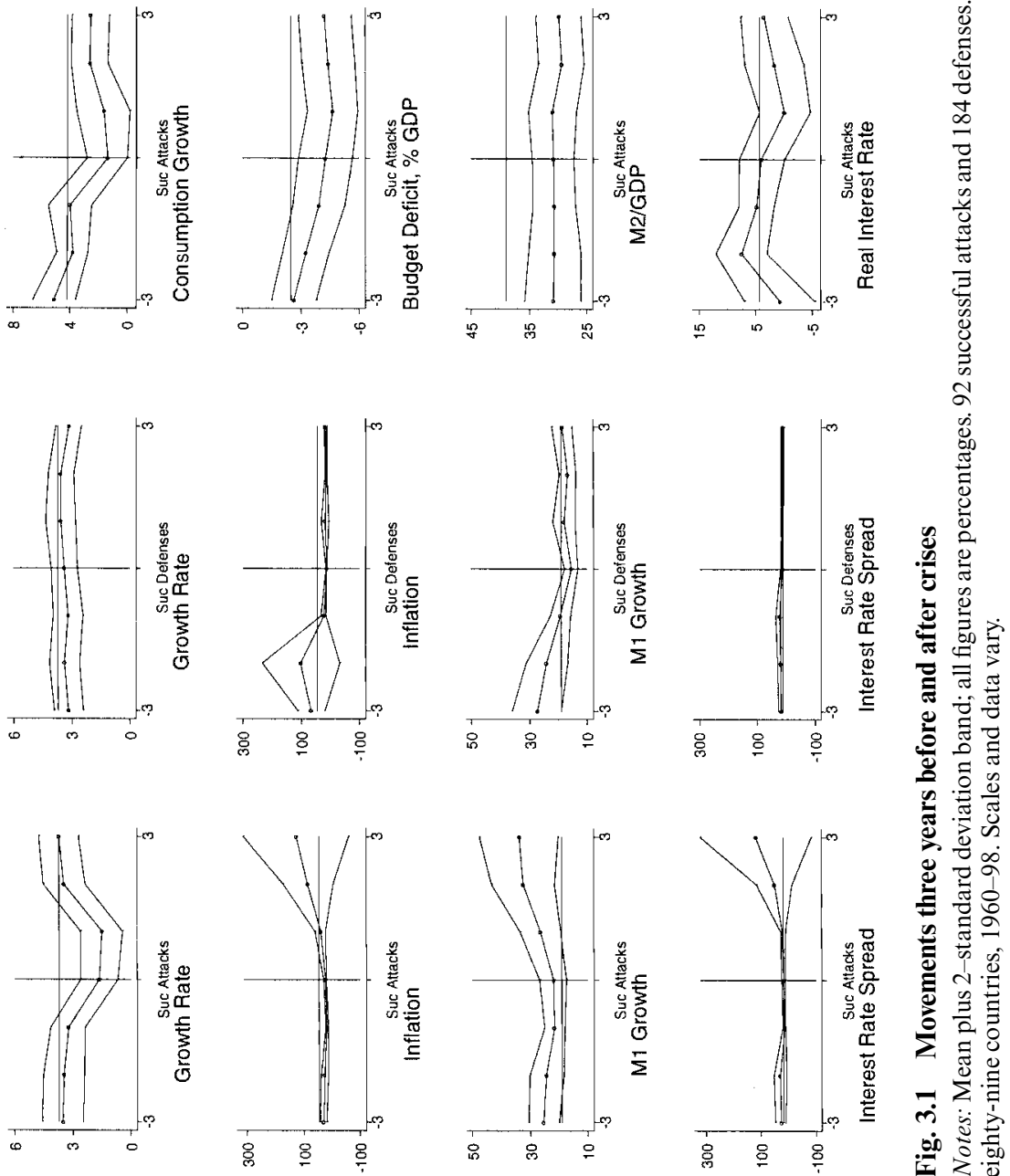

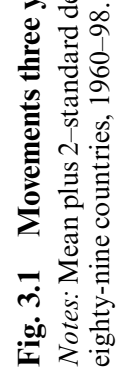



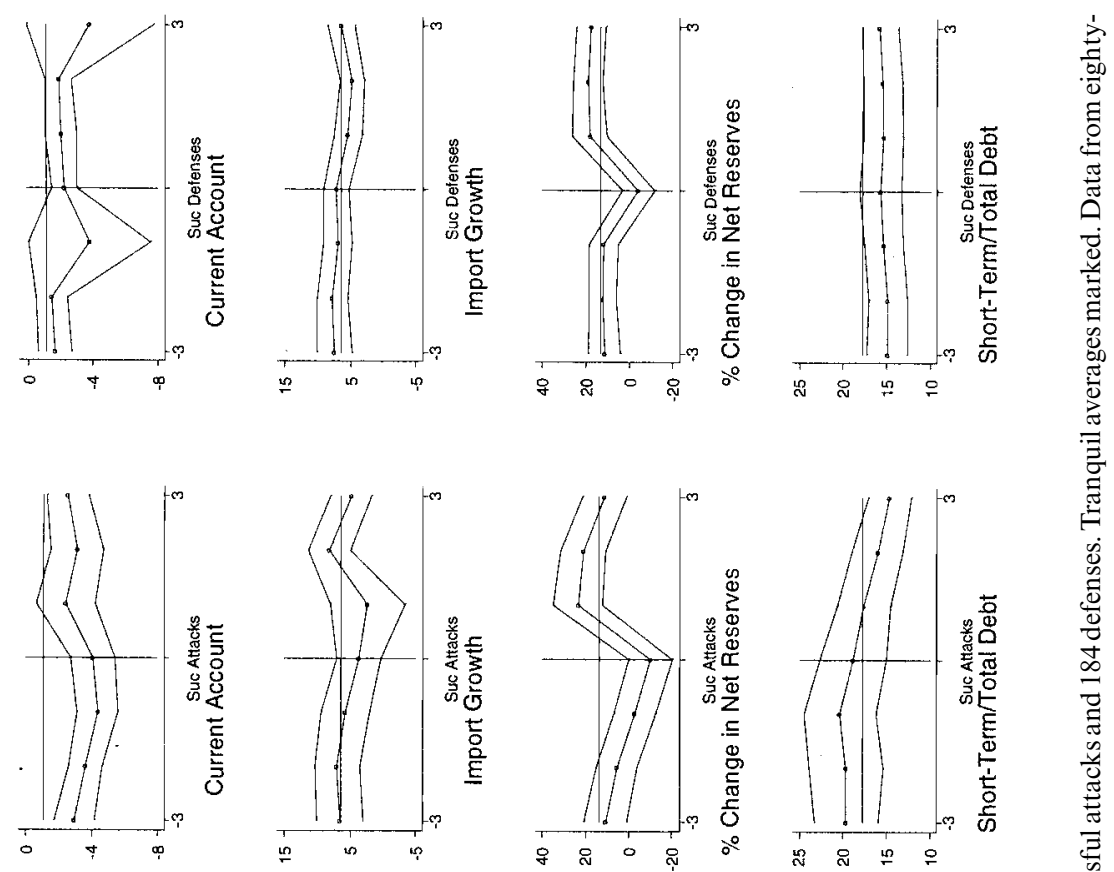

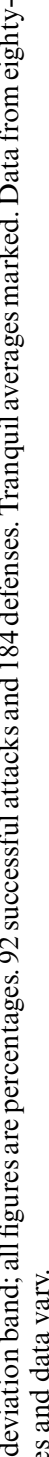
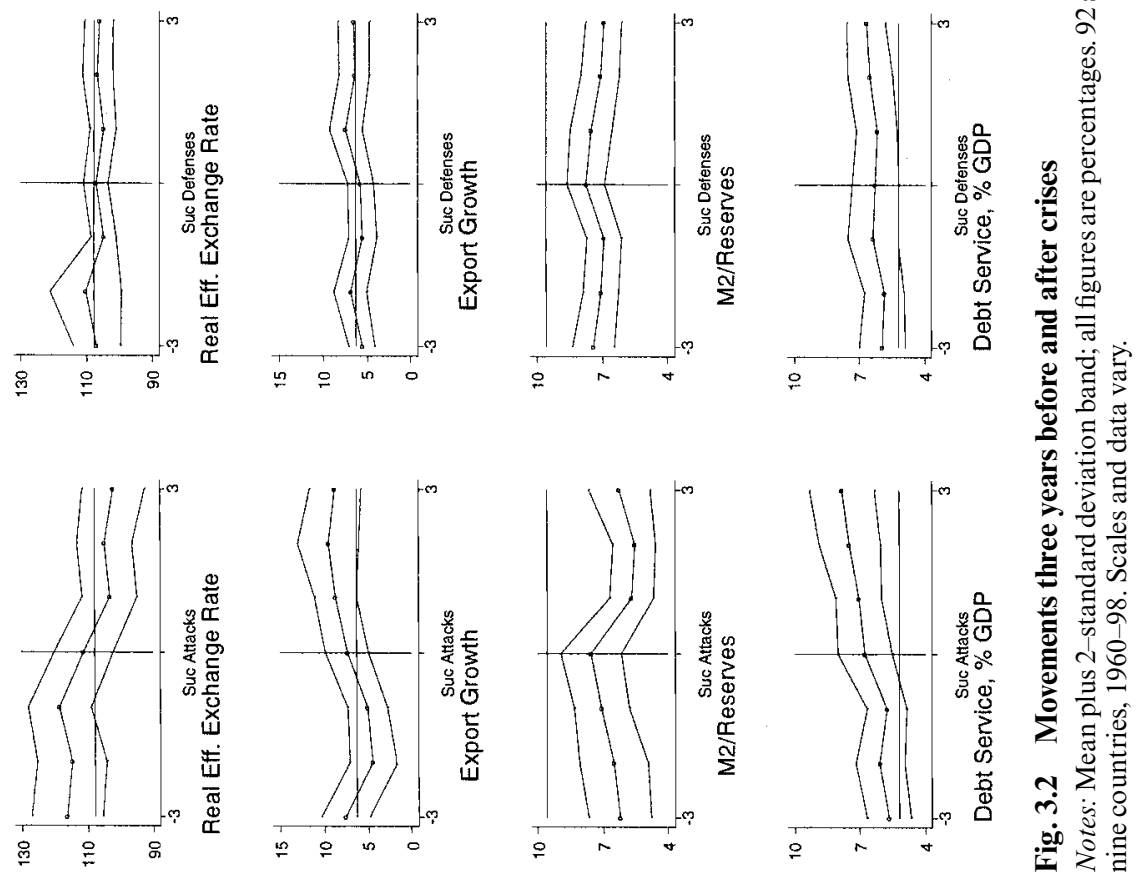
Figure 3.2 provides analogous evidence for external variables. Countries that experience a crisis display somewhat more real exchange rate appreciation, larger current account deficits, and higher ratios of debt service to GNP (compared to countries that do not) prior to the event. This consistent with mainstream models of the determinants of speculative attacks. ${ }^{12}$ However, to repeat, our concern in this paper is not whether there are differences between countries that do and do not experience crises, but whether there are differences in the pre-crisis behavior of these variables between countries that mount successful and unsuccessful defenses. While there is some sign that countries that are unable to defend against speculative attacks tend to have more short-term debt in their total debt loan and to have experienced more real effective exchange rate appreciation in the run-up to the crisis (compared to the successful defenders), in no case is the behavior of these variables significantly different from in tranquil periods (as indicated by the 2-standard deviation bands), and in no case is the behavior of these variables significantly different between successful attacks and successful defenses in the year preceding the crisis. ${ }^{13}$ There are no differences between successful attacks and successful defenses in the size of the current account deficit in the year immediately preceding the crisis, and there are no discernible differences in the consequent debt service burdens. ${ }^{14} \mathrm{We}$ cannot reject (at anything approaching conventional confidence levels) the null that these external variables behave the same in the successful attack and successful defense cases in the year immediately preceding the crisis.

Following the crisis, the real effective exchange rate depreciates in countries that abandon defense of their currencies, relative to both the no-crisis cases and the successful defenders. Export growth accelerates and current accounts strengthen, consistent with the aforementioned collapse of consumption. These patterns are consistent with the very different post-crisis behavior of GNP growth in countries that mount successful and unsuccessful defenses against speculative attacks. ${ }^{15}$

Tables 3.1 through 3.3 take a different look at this same question. We now ask not whether there are significant differences in the behavior of these variables before successful attacks and successful defenses (which was the question that occupied us before), but whether there is evidence that a given value of these variables has a different impact on the likelihood of successful attacks and successful defenses. Table 3.1 is most directly comparable to

12. For completeness, we note that the differences between the crisis and noncrisis countries are statistically significant at conventional confidence levels for the current account but not for the other two variables.

13. Formally, we are unable to reject the null that their values are the same in successful attacks and successful defenses at the 95 percent confidence level.

14. The statement in the preceding footnote again applies.

15. However, the evolution of none of these three variables differs significantly (that is, at the 95 percent confidence level) in the post-crisis period between successful and unsuccessful defenders. 


\begin{tabular}{|c|c|c|c|c|}
\hline & \multicolumn{2}{|c|}{ Year Before } & \multicolumn{2}{|c|}{ Year After } \\
\hline & $\begin{array}{c}\text { Successful } \\
\text { Attacks }\end{array}$ & $\begin{array}{c}\text { Successful } \\
\text { Defenses }\end{array}$ & $\begin{array}{c}\text { Successful } \\
\text { Attacks }\end{array}$ & $\begin{array}{c}\text { Successful } \\
\text { Defenses }\end{array}$ \\
\hline GDP growth & $\begin{array}{c}-0.02 \\
(0.02)\end{array}$ & $\begin{array}{c}-0.00 \\
(0.02)\end{array}$ & $\begin{array}{c}-0.06 \\
(0.02)\end{array}$ & $\begin{array}{c}0.01 \\
(0.02)\end{array}$ \\
\hline Consumption growth & $\begin{array}{c}0.00 \\
(0.02)\end{array}$ & $\begin{array}{c}-0.01 \\
(0.02)\end{array}$ & $\begin{array}{c}-0.06 \\
(0.02)\end{array}$ & $\begin{array}{c}-0.02 \\
(0.02)\end{array}$ \\
\hline Budget ( $\%$ GDP) & $\begin{array}{c}-0.05 \\
(0.03)\end{array}$ & $\begin{array}{c}-0.03 \\
(0.03)\end{array}$ & $\begin{array}{c}-0.08 \\
(0.03)\end{array}$ & $\begin{array}{c}-0.06 \\
(0.03)\end{array}$ \\
\hline M1 growth & $\begin{array}{c}0.001 \\
(0.004)\end{array}$ & $\begin{array}{l}-0.00 \\
(0.010)\end{array}$ & $\begin{array}{c}0.004 \\
(0.003)\end{array}$ & $\begin{array}{l}-0.01 \\
(0.010)\end{array}$ \\
\hline M2 growth & $\begin{array}{c}-0.001 \\
(0.002)\end{array}$ & $\begin{array}{c}-0.002 \\
(0.002)\end{array}$ & $\begin{array}{c}0.000 \\
(0.001)\end{array}$ & $\begin{array}{l}-0.01 \\
(0.010)\end{array}$ \\
\hline Interest rate spread & $\begin{array}{l}-0.000 \\
(0.002)\end{array}$ & $\begin{array}{l}-0.002 \\
(0.003)\end{array}$ & $\begin{array}{c}0.000 \\
(0.002)\end{array}$ & $\begin{array}{l}-0.003 \\
(0.005)\end{array}$ \\
\hline Real interest rate & $\begin{array}{c}0.01 \\
(0.01)\end{array}$ & $\begin{array}{c}-0.00 \\
(0.01)\end{array}$ & $\begin{array}{c}-0.01 \\
(0.01)\end{array}$ & $\begin{array}{c}0.02 \\
(0.01)\end{array}$ \\
\hline Current account ( $\%$ GDP) & $\begin{array}{c}-0.04 \\
(0.02)\end{array}$ & $\begin{array}{c}-0.04 \\
(0.02)\end{array}$ & $\begin{array}{c}-0.02 \\
(0.02)\end{array}$ & $\begin{array}{c}-0.01 \\
(0.02)\end{array}$ \\
\hline Export growth & $\begin{array}{c}-0.01 \\
(0.01)\end{array}$ & $\begin{array}{l}-0.01 \\
(0.01)\end{array}$ & $\begin{array}{c}0.02 \\
(0.01)\end{array}$ & $\begin{array}{c}0.01 \\
(0.01)\end{array}$ \\
\hline Import growth & $\begin{array}{c}-0.00 \\
(0.01)\end{array}$ & $\begin{array}{c}0.00 \\
(0.01)\end{array}$ & $\begin{array}{c}-0.02 \\
(0.01)\end{array}$ & $\begin{array}{c}-0.00 \\
(0.01)\end{array}$ \\
\hline M2/GDP & $\begin{array}{l}-0.01 \\
(0.010)\end{array}$ & $\begin{array}{c}0.002 \\
(0.005)\end{array}$ & $\begin{array}{l}-0.01 \\
(0.010)\end{array}$ & $\begin{array}{c}0.002 \\
(0.005)\end{array}$ \\
\hline M3/GDP & $\begin{array}{l}-0.01 \\
(0.010)\end{array}$ & $\begin{array}{c}0.005 \\
(0.004)\end{array}$ & $\begin{array}{l}-0.01 \\
(0.010)\end{array}$ & $\begin{array}{c}0.001 \\
(0.005)\end{array}$ \\
\hline CPI inflation & $\begin{array}{l}-0.001 \\
(0.0010)\end{array}$ & $\begin{array}{l}-0.001 \\
(0.0020)\end{array}$ & $\begin{array}{c}-0.0001 \\
(0.0005)\end{array}$ & $\begin{array}{l}-0.01 \\
(0.0100)\end{array}$ \\
\hline GDP inflation & $\begin{array}{l}-0.001 \\
(0.0020)\end{array}$ & $\begin{array}{l}-0.002 \\
(0.0020)\end{array}$ & $\begin{array}{c}-0.002 \\
(0.0005)\end{array}$ & $\begin{array}{l}-0.01 \\
(0.0100)\end{array}$ \\
\hline M2/reserves & $\begin{array}{c}-0.01 \\
(0.01)\end{array}$ & $\begin{array}{c}-0.02 \\
(0.01)\end{array}$ & $\begin{array}{c}-0.03 \\
(0.02)\end{array}$ & $\begin{array}{c}-0.02 \\
(0.01)\end{array}$ \\
\hline $\begin{array}{l}\text { Net international reserves } \\
\quad(\% \text { change })\end{array}$ & $\begin{array}{l}-0.008 \\
(0.002)\end{array}$ & $\begin{array}{l}-0.000 \\
(0.003)\end{array}$ & $\begin{array}{c}0.005 \\
(0.002)\end{array}$ & $\begin{array}{l}0.005 \\
(0.002)\end{array}$ \\
\hline Real effective exchange rate & $\begin{array}{c}0.005 \\
(0.003)\end{array}$ & $\begin{array}{c}-0.003 \\
(0.006)\end{array}$ & $\begin{array}{c}-0.004 \\
(0.007)\end{array}$ & $\begin{array}{c}-0.004 \\
(0.005)\end{array}$ \\
\hline$\$$ Exchange rate ( $\%$ change) & $\begin{array}{l}-0.000 \\
(0.004)\end{array}$ & $\begin{array}{l}-0.002 \\
(0.004)\end{array}$ & $\begin{array}{c}0.008 \\
(0.002)\end{array}$ & $\begin{array}{c}-0.004 \\
(0.004)\end{array}$ \\
\hline Short-term/total debt & $\begin{array}{c}0.01 \\
(0.01)\end{array}$ & $\begin{array}{c}-0.01 \\
(0.01)\end{array}$ & $\begin{array}{c}0.00 \\
(0.01)\end{array}$ & $\begin{array}{c}-0.03 \\
(0.01)\end{array}$ \\
\hline Debt service $(\%$ GDP $)$ & $\begin{array}{c}0.01 \\
(0.03)\end{array}$ & $\begin{array}{c}0.02 \\
(0.04)\end{array}$ & $\begin{array}{c}0.08 \\
(0.03)\end{array}$ & $\begin{array}{c}0.03 \\
(0.04)\end{array}$ \\
\hline
\end{tabular}

Notes: Multinomial logit regression coefficients (z-statistics). Default cell is tranquility. Each row tabulates coefficients from two separate logits (before and after crises). Three-year exclusion window ( 82 successful, 85 failed attacks). Intercepts not reported. Entries in bold indicate that the coefficients differ between successful and failed attacks at the $90 \%$ confidence level. 
Table 3.2

Multivariate Multinomial Logit Results: Year Before Crises

\begin{tabular}{|c|c|c|c|c|c|c|}
\hline & $\begin{array}{c}\text { Successful } \\
\text { Attacks }\end{array}$ & $\begin{array}{c}\text { Successful } \\
\text { Defenses }\end{array}$ & $\begin{array}{c}\text { Successful } \\
\text { Attacks }\end{array}$ & $\begin{array}{c}\text { Successful } \\
\text { Defenses }\end{array}$ & $\begin{array}{c}\text { Successful } \\
\text { Attacks }\end{array}$ & $\begin{array}{r}\text { Successful } \\
\text { Defenses }\end{array}$ \\
\hline GDP growth & $\begin{array}{c}-0.04 \\
(0.04)\end{array}$ & $\begin{array}{c}-0.00 \\
(0.04)\end{array}$ & $\begin{array}{c}-0.07 \\
(0.04)\end{array}$ & $\begin{array}{c}-0.05 \\
(0.05)\end{array}$ & $\begin{array}{c}-0.15 \\
(0.05)\end{array}$ & $\begin{array}{l}-0.07 \\
(0.05)\end{array}$ \\
\hline Inflation & $\begin{array}{l}-0.004 \\
(0.003)\end{array}$ & $\begin{array}{l}-0.004 \\
(0.003)\end{array}$ & & & & \\
\hline Budget deficit & $\begin{array}{l}-0.08 \\
(0.04)\end{array}$ & $\begin{array}{l}-0.08 \\
(0.04)\end{array}$ & & & & \\
\hline Current account & $\begin{array}{c}-0.03 \\
(0.04)\end{array}$ & $\begin{array}{c}0.02 \\
(0.03)\end{array}$ & & & & \\
\hline M2/GDP & $\begin{array}{c}-0.03 \\
(0.01)\end{array}$ & $\begin{array}{c}-0.02 \\
(0.01)\end{array}$ & & & & \\
\hline Interest spread & & & $\begin{array}{l}-0.003 \\
(0.005)\end{array}$ & $\begin{array}{l}-0.001 \\
(0.004)\end{array}$ & & \\
\hline $\begin{array}{r}\text { Short-term/ } \\
\text { total debt }\end{array}$ & & & $\begin{array}{c}0.05 \\
(0.02)\end{array}$ & $\begin{array}{c}0.03 \\
(0.03)\end{array}$ & & \\
\hline Debt service & & & $\begin{array}{l}-0.03 \\
(0.04)\end{array}$ & $\begin{array}{l}-0.05 \\
(0.06)\end{array}$ & & \\
\hline $\begin{array}{l}\text { Real effective } \\
\text { exchange rate }\end{array}$ & & & & & $\begin{array}{c}0.01 \\
(0.01)\end{array}$ & $\begin{array}{c}-0.00 \\
(0.01)\end{array}$ \\
\hline M2/reserves & & & & & $\begin{array}{l}-0.07 \\
(0.03)\end{array}$ & $\begin{array}{l}-0.03 \\
(0.02)\end{array}$ \\
\hline$N$ & \multicolumn{2}{|c|}{460} & \multicolumn{2}{|c|}{269} & \multicolumn{2}{|c|}{335} \\
\hline Pseudo- $R^{2}$ & \multicolumn{2}{|c|}{0.05} & \multicolumn{2}{|c|}{0.04} & \multicolumn{2}{|c|}{0.06} \\
\hline $\begin{array}{l}\text { Equality test } \\
\text { ( } P \text {-value) }\end{array}$ & \multicolumn{2}{|c|}{0.67} & \multicolumn{2}{|c|}{0.97} & \multicolumn{2}{|c|}{0.29} \\
\hline
\end{tabular}

Notes: Multinomial logit estimation: $z$-statistics in parentheses. Default cell is tranquility. Intercepts not reported. Three-year exclusion window ( 82 successful, 85 failed attacks).

figures 3.1 and 3.2, in that we consider the variables one at a time (in simple bivariate regressions). The first two columns confirm that there are few significant differences in the impact of these variables between the default state (tranquility) and the crisis state in the year preceding the event. The conclusion holds for both successful attacks and successful defenses. Similarly, there are few significant differences in their impact between successful attacks and successful defenses in the immediately preceding period. In particular, differences are evident only in the effect of financial depth, for which we do not have an explanation, and in the effect of changes in international reserves, which is inevitable, given the way we define successful attacks and successful defenses. Recall that successful attacks are cases in which reserve losses have a large effect — in the present context, a large coefficient —on the probability of an exchange rate change, whereas successful defenses are cases in which reserve losses - in the present context, evidence of an attack - do not have an analogous effect. Thus, it must be the case that we obtain different coefficients on the net change in reserves prior to successful 
Table 3.3

Multivariate Multinomial Logit Results: Year After Crises

\begin{tabular}{|c|c|c|c|c|c|c|}
\hline & $\begin{array}{c}\text { Successful } \\
\text { Attacks }\end{array}$ & $\begin{array}{l}\text { Successful } \\
\text { Defenses }\end{array}$ & $\begin{array}{c}\text { Successful } \\
\text { Attacks }\end{array}$ & $\begin{array}{l}\text { Successful } \\
\text { Defenses }\end{array}$ & $\begin{array}{l}\text { Successful } \\
\text { Attacks }\end{array}$ & $\begin{array}{c}\text { Successful } \\
\text { Defenses }\end{array}$ \\
\hline GDP growth & $\begin{array}{l}-0.15 \\
(0.03)\end{array}$ & $\begin{array}{c}-0.03 \\
(0.04)\end{array}$ & $\begin{array}{c}-0.14 \\
(0.04)\end{array}$ & $\begin{array}{c}0.06 \\
(0.05)\end{array}$ & $\begin{array}{c}-0.16 \\
(0.04)\end{array}$ & $\begin{array}{c}-0.02 \\
(0.05)\end{array}$ \\
\hline Inflation & $\begin{array}{c}-0.001 \\
(0.001)\end{array}$ & $\begin{array}{l}-0.020 \\
(0.010)\end{array}$ & & & & \\
\hline Budget deficit & $\begin{array}{l}-0.10 \\
(0.03)\end{array}$ & $\begin{array}{l}-0.11 \\
(0.04)\end{array}$ & & & & \\
\hline Current account & $\begin{array}{c}0.04 \\
(0.03)\end{array}$ & $\begin{array}{l}-0.01 \\
(0.03)\end{array}$ & & & & \\
\hline M2/GDP & $\begin{array}{c}-0.03 \\
(0.01)\end{array}$ & $\begin{array}{l}-0.01 \\
(0.01)\end{array}$ & & & & \\
\hline Interest spread & & & $\begin{array}{l}-0.002 \\
(0.004)\end{array}$ & $\begin{array}{l}-0.002 \\
(0.007)\end{array}$ & & \\
\hline $\begin{array}{r}\text { Short-term/ } \\
\text { total debt }\end{array}$ & & & $\begin{array}{l}0.060 \\
(0.02)\end{array}$ & $\begin{array}{l}0.001 \\
(0.03)\end{array}$ & & \\
\hline Debt service & & & $\begin{array}{c}0.06 \\
(0.04)\end{array}$ & $\begin{array}{l}-0.02 \\
(0.05)\end{array}$ & & \\
\hline $\begin{array}{l}\text { Real effective } \\
\text { exchange rate }\end{array}$ & & & & & $\begin{array}{c}-0.01 \\
(0.01)\end{array}$ & $\begin{array}{c}-0.00 \\
(0.01)\end{array}$ \\
\hline M2/reserves & & & & & $\begin{array}{l}-0.10 \\
(0.05)\end{array}$ & $\begin{array}{l}-0.03 \\
(0.02)\end{array}$ \\
\hline$N$ & \multicolumn{2}{|c|}{486} & \multicolumn{2}{|c|}{282} & \multicolumn{2}{|c|}{353} \\
\hline Pseudo- $R^{2}$ & \multicolumn{2}{|c|}{0.11} & \multicolumn{2}{|c|}{0.08} & \multicolumn{2}{|c|}{0.07} \\
\hline $\begin{array}{l}\text { Equality test } \\
\text { exchange rate }\end{array}$ & \multicolumn{2}{|c|}{0.01} & \multicolumn{2}{|c|}{0.01} & \multicolumn{2}{|c|}{0.07} \\
\hline
\end{tabular}

Notes: Multinomial Logit Estimation: $z$-statistics in parentheses. Default cell is tranquility. Intercepts not reported. Three-year exclusion window ( 82 successful, 85 failed attacks).

attacks and successful defenses. (Note that we are discussing here the effect of reserve losses on the outcome, not the size of those reserve losses. In fact, reserves are actually smaller and fall faster prior to successful defenses, which cuts against the argument that successful attacks are those that are somehow more intense.)

On the other hand, a number of significant differences are evident in the year following the crisis, most notably in the behavior of gross domestic product (GDP) growth, as we emphasize throughout the paper, but also in money growth, import growth, the real interest rate, and the ratio of saving accounts (M2) to GNP.

In sum, we find that failure to successfully defend the currency against attack has real costs in terms of GNP. That post-crisis decline in growth is not obviously attributable to precrisis characteristics of the economy (compared to countries that successfully defend the currency against attack). The proximate source of that decline in growth in turn is the fall decline in consumption and rise in the risk premium, suggesting a deterioration in 
confidence. Although the real exchange rate, export growth, and the current account buffer these negative effects, they do so incompletely. The acceleration of M1 growth and inflation suggests that it is loss of the monetary anchor and of monetary discipline that lies behind the deterioration in confidence and precipitates the output losses.

\subsection{Multivariate Analysis}

The preceding comparisons are univariate. We now turn to multivariate analysis, drawing models from the literature on the determinants of currency crises.

Again, we first ask whether there is any evidence that economic and financial variables have different impacts on the likelihood of a successful attack and a successful defense, now considering a variety of such variables simultaneously. We then ask whether the pre- and post-crisis behavior of output and other variables differs significantly depending on the success or failure of the attack, now controlling for other characteristics of the economy. The null is that the evolution and effects of the variables of interest are statistically distinguishable from one another before (after) successful attacks and successful defenses.

Tables 3.2 and 3.3 summarize the results of estimating a series of multinomial logit models by maximum likelihood. Table 3.2 contains estimates for three different specifications, using data for the year preceding the crisis. Table 3.3 reports the same three specifications, but using data for the year following the crisis. We report the coefficients and their associated $z$ statistics (the latter in absolute value terms).$^{16}$ Tranquility (i.e., observations that are not within three years of an attack) is the default cell; the coefficients therefore capture the differential impact of a variable on the probability of a successful attack or a successful defense, compared to the tranquil default state.

The bottom of the table provides various diagnostics and hypothesis tests. The most important of these is the $p$-value for the test statistic that the coefficients are identical for the successful attacks and the successful defenses. A high number is consistent with the hypothesis, whereas a low one rejects it.

The default specification is at the left of the table: it includes growth, inflation, measures of monetary and fiscal policy, the interest rate, and the current account. ${ }^{17}$ The fit (as measured by the $R^{2}$ ) is predictably unimpres-

16. All slopes are multiplied by 100 . Constants are included in the regressions but not recorded.

17. This specification is not the result of extensive pretesting; rather, we simply adopt the specification used to analyze the correlates of crises in Eichengreen and Rose (2000b). However, to establish robustness, we also display the results of estimating two additional specifications. 


\begin{tabular}{lcccccc}
\hline & & & & & Without High & One-Year \\
Inflation Obs & $\begin{array}{c}\text { Window } \\
(5)\end{array}$ \\
\hline Lagged successful & -3.19 & -1.22 & -3.76 & -3.20 & -3.06 & -2.80 \\
$\quad$ attack & $(0.82)$ & $(0.59)$ & $(1.19)$ & $(0.83)$ & $(0.88)$ & $(0.72)$ \\
Lagged successful & -0.61 & -0.09 & -0.98 & 0.64 & -0.81 & 0.11 \\
$\quad$ defense & $(0.64)$ & $(0.56)$ & $(0.92)$ & $(0.66)$ & $(0.69)$ & $(0.57)$ \\
Lagged growth & 0.36 & 1.91 & 0.39 & 0.35 & 0.36 & 0.36 \\
& $(0.05)$ & $(0.24)$ & $(0.07)$ & $(0.04)$ & $(0.05)$ & $(0.05)$ \\
Lagged inflation & 0.01 & & 0.01 & 0.01 & 0.01 & 0.01 \\
& $(0.01)$ & & $(0.01)$ & $(0.01)$ & $(0.01)$ & $(0.01)$ \\
Lagged budget & -0.02 & & -0.01 & -0.01 & -0.03 & -0.02 \\
$\quad$ deficit & $(0.04)$ & & $(0.04)$ & $(0.04)$ & $(0.05)$ & $(0.04)$ \\
Lagged money & -0.01 & & 0.01 & 0.01 & -0.01 & -0.01 \\
$\quad$ growth & $(0.01)$ & & $(0.01)$ & $(0.01)$ & $(0.01)$ & $(0.01)$ \\
Lagged current & & & -0.05 & & & \\
$\quad$ account def. & & & $(0.07)$ & & & \\
Lagged interest & & & -0.01 & & & \\
$\quad$ rate spread & & & $(0.01)$ & & & \\
Capital controls & & & & -0.41 & & \\
& & & & $(0.29)$ & & 0.16 \\
$R^{2}$ & 0.17 & 0.20 & 0.22 & 0.17 & 0.17 & \\
$N$ & 1,003 & 2,501 & 580 & 983 & 903 &
\end{tabular}

Note: Constant terms estimated but not reported. Standard errors in parentheses.

sive, consistent with the generally poor performance of leading-indicator models. ${ }^{18}$ However, what matters is that there continue to be few significant differences between successful attacks and successful defenses before the event, but a variety of significant differences thereafter. An alternative specification (in the middle two columns) uses a trio of financial variables as controls: the interest rate spread, the share of short-term debt in the external debt burden, and the ratio of debt service to GDP. Still another specification (in the last two columns) substitutes two measures of external vulnerability: reserve adequacy (the M2-reserve ratio) and the real effective exchange rate. The results for output are the same regardless of the choice of controls.

Table 3.4 quantifies the cost of a successful speculative attack. It reports the results of regressing the growth rate of real GDP on one-year lags of dummy variables for successful attacks and successful defenses, along with a variety of controls. If speculative attacks, whether successful or unsuccessful, have no effect on growth rates after a year, then the coefficients on both dummy variables should be zero. However, given what we have seen so

18. This is something we have emphasized elsewhere; see Eichengreen and Rose (2001a). 
far, we expect the coefficient on the lag of a successful attack to be negative, large, and significantly different from zero. We expect the coefficient on successful defenses to be less important and to differ significantly from the coefficient on successful attacks.

Table 3.4 shows six variants of this output equation, estimated on a variety of controls and samples. Regardless of sample and specification, we find that both hypotheses are supported. The coefficients indicate a significant negative effect on output in the case of successful attacks but not in the case of successful defenses. In each case, the coefficients on successful attacks and successful defenses differ from one another at conventional confidence level. The results suggest that the cost of a successful attack (relative to a successful defense) is 2-3 percentage points of GDP.

\subsection{Sensitivity Analysis}

In this section we report additional sensitivity analysis in order to establish the robustness of our findings. We first consider a variety of perturbations of the basic methodology, and we then implement a variety of further corrections for observable and unobservable heterogeneity.

\subsubsection{Perturbations of the Methodology}

In perturbing the basic methodology, we started with our default specification, which includes inflation, the budget and current account balances (relative to GDP, multiplied by 100), and the ratio of M2 to GDP. We then made the following changes. We

- substituted a one-year exclusion window for the three-year window;

- added the IMF dummy for the presence or absence of capital controls;

- added the trio of financial controls (the interest rate spread, the share of short-term debt in the external debt burden, and the ratio of debt service to GDP) to the benchmark specification (rather than substituting them, as in table 3.4);

- added controls for external vulnerability (reserve adequacy and the real effective exchange rate) to the benchmark specification (rather than substituting them, as in table 3.4);

- dropped the high-inflation countries (defined as countries with inflation in excess of 100 percent per annum);

- added a measure of (lagged) banking crises, to test whether countries with financial-sector problems were both less able to mount a successful defense and more likely to suffer large output losses subsequently;

- added lags of currency crises to test whether countries that suffered from chronic exchange-rate problems were both less able to defend (reflecting, inter alia, less credibility) and more likely to suffer severe recessions when attacked; 
Table 3.5

$P$-Values for Test of Equality of Slopes for Successful Attacks and Successful Defenses

\begin{tabular}{lcc}
\hline & Year Before Crises & Year After Crises \\
\hline One-year windowing & 0.73 & 0.00 \\
With IMF capital controls measure added & 0.53 & 0.00 \\
Benchmark + financial & 0.89 & 0.01 \\
Benchmark + external & 0.84 & 0.05 \\
Without high inflation observations & 0.32 & 0.01 \\
With banking crises & 0.49 & 0.07 \\
With lagged currency crises & 0.64 & 0.00 \\
Without OECD observations & 0.73 & 0.02 \\
With per capita income interactions added & 0.45 & 0.02 \\
With country credit rating added & 0.45 & 0.00
\end{tabular}

Notes: A low $P$-value number indicates rejection of the hypothesis that the slopes for successful and failed attacks are identical. Default multinomial logit specification, with five macro regressors.

- dropped Organization for Economic Cooperation and Development (OECD) countries;

- added interaction terms between successful attacks and successful defenses on the one hand and per capita income on the other as a way of testing whether the output effects of successful defenses are smaller in high-income countries.

Many of these perturbations yield interesting and plausible results. For example, countries that suffered currency crises in previous periods are more likely to suffer currency crises in the current period. However, critically, none of these changes significantly weakens either of our key results. Table 3.5 reports the relevant $p$-values (where a low number indicates that we can reject the null that output growth is the same for successful and unsuccessful attacks). It will be evident that none of these perturbations modifies the finding that successful attacks and successful defenses are essentially indistinguishable prior to the event. Similarly, the evidence of a more severe post-crisis recession in countries that fail to rebuff the attack remains robust. Interestingly, there is only weak evidence that the output effects of successful attacks are smaller in high-income countries (the interaction term between successful attacks and per capita income has the expected sign - indicating smaller effects in high-income countries - but it is insignificant at standard confidence levels).

\subsubsection{Other Sources of Heterogeneity}

A potential objection to our results is that countries that fail to defend themselves against speculative attacks differ in ways that are not easily captured by standard macroeconomic and financial aggregates. These unobservable characteristics could both make it more difficult for their govern- 
ments to defend the currency against attack and lead to disappointingly weak economic performance in the subsequent period. For example, the Asian crisis trained the spotlight on the importance of bank regulation for economic and financial stability. In this case, the argument would be that a hidden problem of nonperforming loans that does not show up in the statistics both makes it more difficult for a government to fend off a speculative attack (it is reluctant to raise interest rates and hold them at higher levels for fear of further aggravating the problems of an already weak banking system) and makes for a deeper recession following the collapse of the currency (because the banking system is in fact weaker than in countries that succeed in mounting a successful defense). It is not the success or failure of the defense per se that produces the different macroeconomic outcome subsequently, in other words, but an omitted third variable (some other characteristic of the country that is difficult to observe by the econometrician) that is responsible for both the success of the attack and the depth of the post-crisis recession.

These difficult-to-observe characteristics of countries are what the rating agencies are in business to detect. We therefore added to our specification the country credit ratings published in Institutional Investor magazine. ${ }^{19} \mathrm{We}$ use annual averages of semiannual ratings, which range from 0 at the bottom to 100 at the top.

Adding credit ratings changes little (again, see table 3.5). Although the raw credit ratings are somewhat higher for countries that succeed in defending their currencies against attack (not surprisingly), the difference is not significant once we control for observable macroeconomic and financial characteristics. Rating-agency intelligence does not suggest, in other words, that countries that succeed and fail to defend their currencies against attack differ significantly before the event in otherwise unobservable ways. Our first result - that countries that succeed and fail to defend themselves against a speculative attack are basically indistinguishable ex ante-survives this extension. So does our second result: countries that are unable to defend themselves against the speculative attack continue to do significantly worse in the post-attack period even after we control for the difficult-to-quantify characteristics captured by their pre-attack credit ratings. ${ }^{20}$

It could be that in focusing on macroeconomic and financial variables we have neglected important political determinants of both the ability of gov-

19. A regression of these credit ratings on country characteristics (on annual data for the 1990 s) yields an $R$-squared of 0.46 (Eichengreen and Mody 2000). Thus, readily quantified economic and financial conditions explain less than half of the variation in this measure, suggesting that it may add value.

20. Following their crises, countries unable to mount successful defenses of course do worse both in terms of output and credit ratings. This reflects the tendency for ratings to follow actual performance. 
ernments to defend their currencies against attack and the severity of the postattack recession. Where the government lacks public support and is unable to credibly commit to policy reform, statements of readiness to, inter alia, raise interest rates to defend the currency will not be taken at face value. High interest rates may be seen as a sign of desperation rather than as a commitment to defend. If such a government is then forced to abandon its exchange rate commitment, doubts about its commitment to the pursuit of sound and stable alternative policies may lead to an unusually severe postcrisis recession. This is the story told of Indonesia following its 1997 crisis, for example. Again, the implication is that a third variable - in this case, political weakness - explains both the failure of the defense and the poor performance of the economy following the crisis; there is no direct connection between the success or failure of the defense and what comes after.

We therefore considered a series of political variables: whether the electoral system was proportional or majoritarian, whether the crisis occurred in a year immediately before or after an election, whether government was divided or the same party controlled all houses of the congress or parliament, whether the government was left or right wing, and whether the political system was presidential or parliamentary. ${ }^{21}$ One finds in the literature on the political economy of exchange rate policy (e.g., Garrett 1998; Leblang 1999; Leblang and Bernhard 2000) arguments for the reasons each of these variables should affect the ability to make credible commitments to defend the rate.

Their introduction changed nothing. There are no statistically significant differences in these political variables either before or after the event. ${ }^{22}$ Adding them reveals no statistically significant differences before successful attacks and successful defenses in the behavior of the major macroeconomic and financial variables. Moreover, their addition does nothing to weaken our finding of large differences in the post-crisis evolution of output as a function of whether defense of the currency was successful.

Some readers will worry that our benchmark specification, even augmented by country credit ratings and political variables, still does not capture ways in which countries that were unable to defend their currencies and subsequently suffered post-crisis recessions differ from other countries. ${ }^{23} \mathrm{We}$ therefore applied an econometric treatment for unobserved heterogeneity. We estimated a first-stage probit designed to explain why some countries succeeded in defending their currencies while others did not, constructed the Inverse Mills Ratio from the residuals of this equation, and added that ratio as an additional explanatory variable to our benchmark regression ex-

21. We thank David Leblang for kindly providing these data.

22. This is true whether we consider them individually in bivariate comparisons, or as a group in multivariate analysis.

23. The criticism to which the rating agencies have been subjected for failing to predict recent crises provides some grounds for this suspicion. 
Determinants of GDP Growth with "Heckit" Correction

\begin{tabular}{lcc}
\hline Output growth lagged & 0.36 & 0.36 \\
& $(0.05)$ & $(0.05)$ \\
Successful attack lagged & -3.2 & -3.2 \\
& $(0.79)$ & $(0.80)$ \\
Successful defense lagged & -0.6 & -0.6 \\
& $(0.5)$ & $(0.5)$ \\
Inflation lagged & & 0.000 \\
& & $(0.001)$ \\
Budget lagged (\% GDP) & & -0.01 \\
& & $(0.05)$ \\
M1 growth lagged & & 0.001 \\
& & $(0.007)$ \\
Observations & 889 & 885 \\
$P$-value: coefficients $=0$ & 0.00 & 0.00 \\
$\rho$ (s.e.) & 0.27 & 0.30 \\
& $(0.12)$ & $(0.13)$ \\
\hline
\end{tabular}

Notes: OLS coefficients (corrected for selection) with robust standard errors. Selection equation includes inflation, M2/GDP, budget deficit ( $\%$ GDP), and current account ( $\%$ GDP).

plaining postattack economic performance. We modeled the success or failure of the defense as a function of inflation, the government deficit-GDP ratio, and the M2-GDP ratio. We used two variants to explain GDP growth. As in table 3.4, our default specification controls for the effects of lagged growth, inflation, the government deficit-GDP ratio, and the growth rate of M1. The alternative specification controls for lagged output growth alone.

Our key finding survives this extension unscathed. As shown in table 3.6, adding the Inverse Mills Ratio to the regression for post-crisis economic performance does not alter the central finding that countries that successfully defend themselves against attacks grow faster in the post-crisis period.

\subsection{Implications}

Summarizing, we find that countries that are unable to defend their currencies against attack experience significant post-crisis output losses compared to countries that mount a successful defense. Those output losses are significant; we consistently obtain estimates on the order of 3 percent of GNP. However plausible the assumption, we detect no evidence that countries that fail to sustain a successful defense and suffer post-crisis output losses enter their crises with greater economic, financial, and political weaknesses than do countries that succeed in repelling the speculative attack and avoiding post-crisis output losses. We do find plausible and significant differences between pre-crisis conditions in countries that do and those that do not experience speculative attacks, but, to repeat, this is not the subject of our paper. 
The output losses that follow failed defenses generally reflect a collapse of consumption, along with some fall in investment. That this takes place despite a decline in real interest rates clearly signals a negative shock to confidence, as does the post-crisis rise in risk premiums in countries that involuntarily abandon their fixed rates. The rise in money growth and inflation in countries that fail to mount a successful defense is a strong hint of where the shock to confidence is originating: namely, it reflects the decline in monetary discipline that follows the loss of the nominal anchor provided by the previously prevailing exchange rate regime.

These results reinforce the findings of previous studies of exits from pegged exchange rates like Eichengreen et al. (1998). These authors analyze twenty-nine exits by developing countries from single-currency pegs or basket pegs to managed exchange rates or independent floats. They find that growth is significantly lower in the year of the exit than in two control groups of countries: those that continued to peg without exiting, and all other developing countries in the World Bank database. Our results are more refined in that the sample of exits is larger, we limit the control group to other countries that also experienced speculative attacks but did not exit, and we control for a variety of economic, financial, and political characteristics of the countries experiencing crises. However, the central conclusion of that previous study continues to hold: exiting involuntarily in response to a crisis is painful and tends to result in significant output losses. It is better for countries seeking to move to greater exchange rate flexibility to do so voluntarily when the currency is strong rather than as the result of an attack.

This previous study speculated that loss of the nominal anchor-that is, of the exchange rate peg that provided the focal point for the country's monetary policy operating strategy - resulted in a loss of policy discipline and of confidence that compounded the crisis. Our paper provides evidence in support of this conjecture.

A final fact that emerges from our study is that defenses, like attacks, are heterogeneous. ${ }^{24}$ This is evident in the relatively large 2 -standard deviation bands that surround the macroeconomic and financial variables in figures 3.1 and 3.2. The negative output effects of failed defenses may average 3 or 4 percentage points of growth, but they vary widely. Some recent casesBrazil in 1998 springs to mind - are notable for having held these costs to lower levels. The popular explanation for their success is that they were quick to put in place an alternative monetary policy operating strategy: Brazil, for example, replaced its currency peg with an explicit inflationtargeting framework. There was no loss of monetary discipline, and the acceleration of inflation was minimal. The risk premium fell rather than ris-

24. The heterogeneity of currency crises - that is to say, speculative attacks - was a theme of Eichengreen, Rose, and Wyplosz (1995). 
ing, and consumption did not collapse. There can be no clearer example of what the authorities should do to minimize the costs of a failed defense.

We see the broader policy implications as follows. There are two types of monetary-cum-exchange rate arrangements that are compatible with a world of high capital mobility. One is a very hard exchange rate peg that the authorities commit to defending unconditionally if attacked. The other is a clear and credible monetary policy operating strategy not oriented around the level of the exchange rate, such as a full-fledged inflation-targeting framework. A very hard peg, supported by a credible commitment to defend it, can prevent costly speculative attacks that collapse the currency, whereas the installation of a clear and credible alternative monetary policy strategy such as inflation targeting, in the event that the decision is taken to abandon the exchange rate anchor, can help to minimize the disturbance to confidence. Soft pegs, with no provision for an alternative monetary anchor, are the worst of all worlds.

\section{References}

Eichengreen, Barry, and Paul Masson, with Hugh Bredenkamp, Barry Johnston, Javier Hamann, Esteban Jadresic, and Inci Otker. 1998. Exit strategies: Policy options for countries seeking greater exchange rate flexibility. IMF Occasional Paper no. 168. Washington, D.C.: International Monetary Fund.

Eichengreen, Barry, and Ashoka Mody. 2000. What explains the changing spreads on emerging-market debt: Fundamentals or market sentiment? In Capital flows and emerging economies, ed. Sebastian Edwards, 107-36. Chicago: University of Chicago Press.

Eichengreen, Barry, and Andrew Rose. 2000a. The empirics of currency and banking crises. Austrian Economic Review 47:395-402.

2000b. Staying afloat when the wind shifts: External factors and emerging market banking crises. In Money: Capital mobility and trade, essays in honor of Robert Mundell, ed. Guillermo Calvo, Rudi Dornbusch and Maurice Obstfeld, 171-206. Cambridge: MIT Press.

Eichengreen, Barry, Andrew Rose, and Charles Wyplosz. 1995. Exchange market mayhem: The antecedents and aftermath of speculative attacks. Economic Policy 21:249-312.

Garrett, Geoffrey. 1998. Partisan politics in the global economy. Cambridge: Cambridge University Press.

Jeanne, Olivier. 1997. Are currency crises self-fulfilling? A test. Journal of International Economics 43:263-86.

Koehler, Horst. 2001. New challenges for exchange rate policy. Remarks at the AsiaEurope (ASEM) Meeting of Finance Ministers. 13 January, Kobe, Japan. Available at [http://www.mof.go.jp/english/asem/aseme03a1.htm].

Kraay, Aart. 1998. Do high interest rates defend currencies against speculative attacks? The World Bank. Unpublished Manuscript.

Leblang, David. 1999. Domestic political institutions and exchange rate commitments in the developing world. International Studies Quarterly 43:599-620. 
Leblang, David A., and William Bernhard. 2000. The politics of speculative attacks in industrial democracies. International Organization 54:291-324.

\section{Comment Richard Portes}

This paper provides convincing evidence of the output costs of failing to defend a currency peg. This is powerful and important, and the empirical work is careful and thorough. But, the interpretation and some of the specific results raise a number of questions.

There are several puzzling results. First, the authors find that no variables characterizing the precrisis state of an economy affect the probability that a speculative attack against its currency will succeed. As they acknowledge, this appears to go against several papers that claim to have identified leading indicators of crises. I myself do not find this particularly surprising. I have been consistently skeptical about the early-warning systems, because they use little theory (or many theories, without discrimination) on lots of numbers and often come close to data mining. Still, it might be helpful if the authors could give us their considered view of why their regressions refuse to reveal any information about when and why attacks succeed rather than fail. That might be difficult, however, since here too there is no underlying model. That weakens their interpretation of the main result, as I shall suggest.

There are other puzzles. No variables characterizing the precrisis state of an economy explain differences in postcrisis performance as between cases of successful attacks and successful defenses. In particular, the magnitude of output loss consequent upon a successful attack seems independent of the precrisis state. This is certainly counterintuitive and indeed goes against the authors' priors, as they tell us.

The role of the real exchange rate in these results is at best confusing, at worst quite surprising. There seems to be no identifiable difference in the behavior of the real exchange rate in the postcrisis period between economies that succumb to a successful attack, going off their currency peg, and those that defend the peg successfully. If the reader too finds this anomalous, see note 15, the "Year After" section of table 3.1, and table 3.3. I cannot believe there is any problem with the data the authors use, but if a successful attack should have any consequences at all relative to successful defense within a year, the expected outcome is real exchange rate depreciation. Again, we are due some attempt at explanation here.

Richard Portes is professor of economics at London Business School and a research associate of the National Bureau of Economic Research. 
The last of my puzzles relates to the central result itself. The International Monetary Fund (IMF) tells a country to tighten both monetary and fiscal policy in order to prop up its currency, and we have regularly witnessed sacrifices to this end - most recently and tragically in Argentina. It is therefore no less than astonishing that a successful defense against speculative attack appears to have no output cost. I doubt that even the strongest proponents of the "franc fort" in the early 1990s would argue that the successful defense of the French franc in the exchange rate mechanism in autumn 1992 was costless. (It is not an out to say that the attacks were ultimately successful in July 1993.) There are many similar examples.

Regarding the output loss due to a failed defense, my prior would have been that the effect would be less strong in more advanced economies with more robust economic institutions. The authors claim to have dealt with this issue (raised at the conference) with the interaction term involving per capita income, in order to assess whether the output effects of successful attacks are smaller in high-income countries. They do indeed find evidence that this is so, but the coefficient is not significant. Still, that is not dealing directly with the conjecture, which suggests simply running the regressions separately for Organization for Economic Cooperation and Development (OECD) and non-OECD countries. I would be very surprised if the output effect were not significantly smaller in the former.

Why should a country try hard to defend against a speculative attack? I doubt that it is simply that they know the Eichengreen-Rose result and are desperately trying to avoid the short-run output cost of a failed defense. Many countries have seen maintaining a currency peg as a long-run issue. The peg may be their last shot at a consistent monetary policy strategy; it may deeply implicate the credibility of policy makers; it may be a key element in a trade or political system that the country takes very seriously; it may be simply that the policy makers are afraid of floating and its implications.

This relates to the authors' interpretation of their key result. They argue that a successful attack shocks the confidence of markets in the prospects for economic stability. "We thus observe a loss of policy discipline." This is a non sequitur, however: that markets become skeptical might in fact induce sensible policy makers to maintain discipline in order to change market perceptions. In any case, if they do lose discipline, we might see an acceleration of money growth, as the authors suggest. This is reminiscent of the secondgeneration crisis models, which the authors know well but leave out of the story. But, they also suggest that we should see a rise in risk premia: this is unrelated to policy discipline, but it would indeed follow from their original story about market confidence. They should decide which interpretation they prefer, or explicitly maintain both (although, as I suggested, they may be contradictory).

Wherever they do end up, their empirical work provides no evidence to 
support either interpretation. Table 3.1 shows no effects of a successful attack on risk premiums, nor on inflation. Moreover, although a standard test shows that the coefficients on money growth do differ between cases of successful attack and successful defense, if you look at the estimated coefficients and $z$-statistics, it is hard to take this very seriously. The story or stories simply do not come out of the data.

\section{Discussion Summary}

Allan Drazen noted that the paper does not make a clear distinction between a successful (and unsuccessful) defense and a successful (and unsuccessful) attack. Either a failed defense or a decision not to attempt a defense might result in a successful attack.

Martin Eichenbaum remarked that it seems from the data that it is a random decision whether to defend, which, to him, seemed improbable.

Andrew $K$. Rose responded that he is looking into attempted defenses only: following Kraay, these are ones in which reserves decreased by a certain percent. Andrew Berg noted that in this case a country's decision to pay back a large loan to the IMF is identified as a successful defense even though there was no attack.

Peter B. Kenen noted that there does not seem to be any difference in interest rate spreads between the two subsets, so it seems there are interest rate defenders in both subsets.

Joshua Aizenman questioned whether it is possible to test directly for the output cost as a result of the loss of the nominal anchor, suggesting that it may be possible by controlling for the duration of the peg and history of previous crises.

Kenneth Kletzer made a reference to previous research that was unable to find leading indicators of crises. Having said that, he noted that in table 3.1 there is a difference in net international reserves prior to the crisis. He suggested that might help explain the paper's findings.

Michael M. Hutchison remarked that devaluing the currency would likely have dynamic long-run effects that are not captured in this model. He suggested extending the sample period in order to capture these reversal effects.

Edwin M. Truman, following others, noted that the Kraay variable of currency crises is problematic, as there are a lot of reasons that reserves can go down. He also noted that it seems likely that either governments that are in a very strong position or ones that are weak choose to attempt a defense. This asymmetry, he suggested, should be accounted for in the model. Third, he asked what the policy implications of the paper's findings are. That depends, he stated, on the exact nature of the crisis in question. 
Martin Feldstein inquired whether the output costs of a defense that the authors find are permanent and, if so, how that can be, since the exogenous effect is of a demand shock.

Vincent Reinhart commented that the output loss could be due to a loss of confidence or to a rejection of the present regime. It might even be caused by the change in regime following the crisis, so it will be beneficial to examine those ex post changes and control for them.

Michael P. Dooley questioned whether the big crises, such as the Mexico 1994 or Asia 1997 crises, are not fundamentally different from the many other small crises in the authors' data set.

Rose responded first to Portes's concern that the paper does not differentiate between OECD and non-OECD countries by noting that it was one of the sensitivity checks in table 3.5. In response to Hutchison, he noted that they did run some long-run regressions covering three years but found significant results were for the first year only. He added that they used other crisis definitions besides Kraay's, but that did not make much difference. He also stated that it seems the status of the banking industry is accounted for by the inclusion of market perceptions in the regressions. He also doubted whether the data would allow differentiation between permanent and temporary effects. Barry Eichengreen responded that he and Andrew Rose planned to follow through on a number of these suggestions, but he was skeptical that doing so would change the central results. He noted that there had been much general discussion of the policy implications of the findings. His take on these implications was that only very hard pegs and relatively free floats are workable in a world of high capital mobility. A hard peg will be workable if the commitment to defend it is fully credible, whereas floating will be feasible provided that the authorities articulate a clear and coherent monetary policy operating strategy such as inflation targeting. Intermediate exchange rate regimes, on the other hand, are a recipe for disaster. 
